\title{
Assessment of Socio-Demographic Factors and Students' Satisfaction with the Study of ICT in Secondary Schools
}

\author{
Valentine Joseph Owan ${ }^{1 \star}$, Michael Ekpenyong Asuquo ${ }^{1}$
}

\author{
${ }^{1}$ Department of Educational Management, University of Calabar, Calabar, NIGERIA \\ *Corresponding Author: owanvalentine@gmail.com
}

Citation: Owan, V. J., \& Asuquo, M. E. (2021). Assessment of Socio-Demographic Factors and Students' Satisfaction with the Study of ICT in Secondary Schools. Pedagogical Research, 6(3), em0101. https://doi.org/10.29333/pr/11087

\begin{tabular}{|c|c|}
\hline ARTICLE INFO & ABSTRACT \\
\hline Received: 21 Feb. 2021 & This research assessed certain socio-demographic variables and how they affect students' satisfaction with the \\
\hline Accepted: 23 May 2021 & $\begin{array}{l}\text { study of ICT in secondary schools. The study adopted a survey research design and was guided by six specific } \\
\text { objectives. A total of 4,484 senior secondary school students represented the study's population, while a simple } \\
\text { random sampling technique was adopted in selecting a sample of 2,242 respondents. Secondary school Students' } \\
\text { Satisfaction with the Study of ICT Questionnaire (SSSSSICTQ)" was used primarily as the tool for data collection. } \\
\text { Although there are differences in students' satisfaction levels across various groups, age, gender, parents' income } \\
\text { level, students' education level and school location do not significantly influence students' satisfaction with the } \\
\text { study of ICT in secondary schools respectively. It was concluded that the socio-demographic factors of students } \\
\text { do not influence to a notable extent, students' satisfaction with the study of ICT in secondary schools. Based on } \\
\text { this conclusion, the implication imposes additional responsibilities for future studies to attempt to uncover } \\
\text { reasons why socio-demographic factors do not affect the satisfaction of students with the study of ICT at the } \\
\text { secondary education level. }\end{array}$ \\
\hline
\end{tabular}

Keywords: ICT study, satisfaction, school management, secondary students, socio-demographic factors

\section{INTRODUCTION}

The curriculum of secondary schools in Nigeria aims at ensuring that graduates are effectively trained to possess relevant Information and Communication Technology (ICT) skills to face the challenges they are likely to meet in the labour market, among other things. At the senior secondary school level, ICT is one of the compulsory subjects expected of students to offer irrespective of their desired field of interest. The introduction of computer studies into the curriculum of secondary education is informed by the revolutionary changes in modern technology across the globe. Thus, its inclusion into the school curriculum and wide adoption does not come as a surprise. ICT in education has become so crucial a component that it has gained considerable attention amongst scholars (Akomolafe, 2008; Odigwe \& Owan, 2020; Uko, et al., 2020). Due to its global use in operating modern organisations, the use of ICT in school administration, teaching and learning, student personnel management, communication and decision making has become unavoidable in the school system (Ekpoh \& Asuquo, 2018).

As an important part of the school curriculum and as an administrative tool, the study of ICT has become pervasive in every educational organization. It is beneficial to students that are either academically weak, strong or with special needs. It is a necessity that can facilitate coping with the ever-changing global educational system and a major driving force behind a country's economic growth (Ogunlade, 2008). Rapid growth and expansion in ICT made it necessary for schools to be innovative in their approach to preparing students for success in the modern world (Dibbon \& Pollock, 2007). Such success is attributed to the development in students' knowledge and skills acquisition in various subjects due to the integration and contribution of ICT (Onuma, 2007). This is justified because, with the advent and inclusion of ICT into the school curriculum, students learn more quickly, demonstrate greater retention and are better motivated when they work with computers (Amenyedzi et al., 2011). In addition, ICT provides learners and educators with basic and usable awareness of the computer, the internet as well as other similar fields (Anumnu, 2008). It is, therefore, imperative to make Nigerian secondary school students, beneficiaries in this regard (Akomolafe, 2008).

In meeting this demand, the Federal Republic of Nigeria (FGN, 2014) stated that the government shall provide adequate infrastructure and develop the capacity for effective utilization of information technology. Despite this declaration by the Federal Government, full implementation of computer studies in schools is yet to be seen and felt (Finani, 2012). Consequently, educational institutions remain ill-equipped with modern ICT facilities, leading to a gross rate of inadequacy (Akomolafe, 2008; Aluko, 2012). This accounts for why more than $95 \%$ of public secondary school students do not have an idea of computer education 
(Nzulumike et al., 2008). The US Census Bureau, in collaboration with five other statistics agencies, developed a facile reaction survey to determine the effect of the COVID-19 pandemic in late April 2020. The Household Pulse Survey assesses a wide range of home-related topics, covering computer and internet access for online education. Generally, 4.4 million student families do not have uninterrupted computer access and 3.7 million do not have access to the internet; while more than half of households had school computers, a small portion of them had internet access devices (USA FACTS, 2020).

In a recent literature review, it was discovered that there are a lot of challenges affecting the adoption and utilization of ICT in Nigeria (Moshood et al., 2020). These problems include high cost of ICT tools, lack of support from private organizations, conservative attitudes of people, low internet connectivity, irregular power supply, network failure, lack of facilities, basic education and computing skills among others (Ekpoh et al., 2013; Ogunlade, 2008). Other problems include poor funding, lack of skills, infrastructure and relevant software devices (Joel et al., 2019). The challenges highlighted above are likely to affect the quality of teaching and learning of ICT in secondary schools, which may in turn, affect students' satisfaction in studying ICT as a subject in schools. Student satisfaction corresponds to the amount of learning behavioural values and practices that arise from collating all the advantages that a student gains while using a blended method (Rahman et al., 2015). Students' satisfaction in this context, refers to a state of being emotionally and artistically fulfilled by what they are being taught in an educational system. Students' internal state of being and the extent of their response to school programmes/activities, instructions and situations are revealing in the technological, creative, employability/entrepreneurial and self-reliant skills they possess. Students' satisfaction is a product of their evaluation of the quality of available learning facilities and educational services rendered to them, and the extent to which these meet their needs and expectations while in school and even after graduation. Assessing secondary school students' satisfaction with computer studies is imperative because the extent to which computer instruction satisfies the needs and expectations of the students may determine the rate at which they learn and perform in the subject.

In any case, many students in developing nations seem to be dissatisfied with learning ICT as a subject in secondary schools. For example, in Ethiopia, 65.4 per cent of high school students were found to be satisfied, while 34.6 per cent were dissatisfied with school service, even though the proportion of dissatisfied students was not substantial (Daniel et al, 2017). Due to the perceived low satisfaction level in the study of ICT, the results of studies have revealed that the use of Moodle can enhance students' satisfaction in ICT (Alkhateeb \& Abdalla, 2021; Goyal \& Purohit, 2011; Pérez-Pérez et al., 2020). The attention of a growing body of research has been drawn towards the assessment of students' satisfaction with web-based learning systems in higher education (Bauk et al., 2014; Himat et al., 2021; Salam \& Farooq, 2020). This implies that the problem of students' satisfaction with the study of ICT at almost all educational levels is gradually gaining international attention. The poor rate of students' satisfaction with the study of ICT, as observed by the researchers and reported by studies, could be responsible for the low rate of ICT skills acquisition and utilization. Studies have revealed that there is a poor degree in the utilisation of ICT resources in secondary schools and higher education, particularly for teaching, research and record maintenance (Agyemang et al. 2019; Odigwe \& Owan, 2020). The rate of poor utilization may be connected to insufficient access to ICT resources.

It has been submitted that "although the new generations seem to be connected to the Internet or a Social Network all the time, the fact is that accessibility to ICT by a sector of society is still a gap to be closed" (Alcántar et al., 2017, p. 3). Another evidence also emerged that students enjoy using ICT facilities and are interested in using computer technology (Fraillon et al., 2014), notwithstanding the inadequate access to resources. To effectively utilize simple ICT gadgets, many secondary school students and graduates patronize computer training centres just to acquire basic ICT skills they ought to have acquired in schools. Upon the completion of such training, they are offered a certificate or diploma in basic computer training and applications. Some secondary school graduates also enrol for ICT studies in training centres to enable them to take computerized qualifying examinations, in preparation for higher education. This phenomenon suggests that the degree of experience and abilities learned by students in ICT at the secondary education level is poor. This study is informed by the reported variations in the utilization of ICT tools among students with different socio-demographic variables.

For example, the evidence from an extensive research showed that females used the internet marginally more (on the average) than males for social contact and there were substantial gender differences in favour of female students in various countries (Australia, Chile, Korea, Lithuania and in three Canadian provinces - Newfoundland, Labrador and Ontario), except for Turkey where male values were substantially higher than female (Fraillon et al., 2014). Other researchers have found ICT utilization to be significantly dependent on the socio-economic level (high, medium and low) of students (Alcántar et al., 2017). It was based on this background that this study was conceived to assess some socio-demographic factors (gender, age, parents' income level, students' educational level and school location) and their respective and interactive effects on students' satisfaction with the study of ICT in secondary schools.

\section{Age and Students' Satisfaction with the Study of ICT}

Literature indicates that age differences in students influence their satisfaction with their studies. For instance, Oluwunmi et al (2017) found that in terms of age, the mean percentage satisfaction of students towards studies was thus; less than 16 years (5\%), 16-20 years (45\%), 21-25 years (46\%), 26-30 years (3\%) and more than 30 years (1\%). Another study demonstrated, after the gender, ethnicity and technology experiences were put under control, that age negatively correlated with internet self-efficacy; again, the correlation between age and course satisfaction was mediated by internet self-efficacy (Liu \& Haque, 2017). The finding of a study in South Texas showed that age and gender predicted students' achievement in face-to-face college algebra courses; however, in the same college algebra online courses, age and gender did not impact students' grade (Amro et al, 2015). In Australia, a study reported among others, that age was one of the statistically significant variables and predictors of academic performance (Considine \& Zappa 2002). This implies that students' achievement may not have been boosted as a result of their dissatisfaction with the online algebra course based on their age. 
On the opposite, the findings of a study revealed no substantial variation in the use of ICT between two classes of teachers based on age and experience (Mahd \& Sa'ad, 2013). It was shown by another research that the age of staff has a major impact on the usage of ICT tools in higher education for teaching, research and record administration; younger lecturers showed greater use of ICT tools than older lecturers in higher education (Odigwe \& Owan, 2020). Another study also showed that college younger students tended to perform better than mature students; therefore, students' age did not correlate with their academic achievement (Craig et al. cited in Amro et al., 2015).

An explanation for the age differences in the utilization of ICT resources is that younger lecturers are less concerned with scholarly work and may have little or no duty to communicate with the family (Odigwe \& Owan, 2020). The scholars assumed that, since they are more curious, young people are more desperate to have ICT services. This is consistent with the position that ICT complies strictly with the rule of decreasing returns and that the use of ICT depreciates as a person grows older (Dei, 2018). Contrary to this, several studies indicate that the usage of ICT services is not significantly influenced by age (Alba \& Trani, 2018; Amua-Sekyi \& Asare, 2016; Mazoya, et al., 2015). In reality, age was not found to affect the time spent on ICT by higher education teachers in Nigeria in a study conducted by Jegede in 2009. Factors related to the existence of respondents, real structures examined, methods used or areas where these studies were carried out can be attributed to the variation in results arrived at by various scholars.

\section{Gender and Students' Satisfaction with the Study of ICT}

Studies have shown differences in students' satisfaction with the quality of service delivery, based on gender. For example, a study revealed substantial gaps between male and female students in their satisfaction with the delivery of university services such as educational, library, medical, travel, defense, hostel and ICT services (Akpoiroro \& Okon, 2015). Similarly, proof from yet another study showed that there is a large disparity in student satisfaction across gender; these differences arise in terms of student-instructor engagement, student support and facility oversight (Daniel et al., 2017). Furthermore, available evidence disclosed that the gender of teachers, as well as, their experiences in the use of computer had an interactive effect on their computer self-efficacy (Sarfo et al., 2017). Despite the evidence, these studies did not provide results on the gender with higher demonstration, satisfaction or utilization of ICT services, resources, and computer self-efficacy.

Closing this gap, the results of a study indicated that learning satisfaction is higher on the part of the males than the female students (Yang et al., 2016). In a further revelation, gender was shown to have a substantial effect on the usage of ICT tools for record management, teaching and research, with males having a higher utilization rate than females (Odigwe \& Owan, 2020). In Ogun State, Nigeria, Oluwunmi et al. (2017) revealed also that male students showed higher levels of satisfaction with ICT and other academic facilities than their female counterparts. It has also been revealed teachers that women made little use of ICT for academic reasons than their men equivalents (Mahdi \& Sa'ad Al-Dera, 2013). For sexuality and academic achievement in mathematics and other science subjects, some studies have shown that male students performed much better than their female counterparts (Musa \& Samuel, 2019; Owan et al., 2020; Salikutluk \& Heyne, 2017; Unodiaku, 2013). Thus, studies tend to reveal male as superiors in the utilization of ICT-related materials.

The gender gap has been attributed to both the roles played by female Africans at school and most notably at home (Odigwe \& Owan, 2020). As a result, the amount of time it takes for female individuals to undergo ICT training could compete with the time required to look after children, family obligations and other educational work. Although gender and performance in different subjects is still a debatable topic, studies have also shown its insignificant role on students' performance (Khadijatu, 2017; Lindberg et al., 2010; Owan, 2020; Owan et al., 2019). These studies on gender and performance have an indirect link to the present study since factors such as satisfaction, utilisation of resources, and study habits affect the performance of students. Therefore, if gender affects performance, it presupposes that such an effect may have resulted from other mediating factors such as satisfaction with the subject in question.

In Edo State, Nigeria, a study on computer literacy and students' academic performance, indicated among others, that female student who were computer literate performed better than their male counterparts who were also computer literate (Aitokhuehi \& Ojogho, 2014). On the contrary, significant gender differences were not found regarding students' satisfaction with ICT studies (Tatli et al., 2011). This is line with the observations of other studies (e.g., Dholakia et al., 2013; Mahdi \& Al-Dera, 2013), which also highlighted that female reported little use of ICT in their teaching than male teachers. This suggests that there is also an ongoing argument over the role of gender on satisfaction and performance of students in ICT. In terms of the interaction between gender and age, no significant effect was found on their computer self-efficacy (Sarfo et al, 2017). However, by showing that they respected ICT for teaching and studying, male and female students shared their satisfaction with ICT studies (Lowerision et al., 2004).

\section{Parents' Income Level and Students' Satisfaction with the Study of ICT}

A study in Ghana found that higher family income correlated with improved academic performance of student; however, family income was not the only predictor of better students' academic success (Adzido, 2016). Income and sources of income affect students' academic achievement; many students from low-income families try on their own to reach the same level of academic achievement as their counterparts whose parents' income are higher; low income directly affects academic achievement negatively as a result of lack of resources for students (Lacour \& Tissington, 2011). In Japan, a study found that some students' academic achievement was not attributed to financial well-to-do parents, but due to family financial strength (Machebe et al., 2017).

In Pakistan, the result of a study showed that both parental income and their level of education positively impacted the performance of the students (Soharwardi et al., 2020). Lower academic achievement was attributed to students from low 
socioeconomic backgrounds, while their counterparts from higher socioeconomic background had corresponding higher academic achievement (Suleman et al, 2012). Although students from the low-income background were able to discover their passion for academics, notwithstanding their parental low income, they were able to succeed academically in school and were also satisfied with their academic achievement (Dias, 2017). Numerous studies tend to reveal that parental income influenced the academic excellence of learners (Finnie \& Mueller, 2008; Joseph, 2016; Odoh et al, 2017; Owan, 2012). On the reverse, in another study, family income was not found as a major marker of learners' academic performance (Considine \& Zappa 2002).

This suggests the need for further research in this area to reinforce and clarify the literature's arguments in terms of the income of parents and the performance of their children. Majority of the cited works were not focused specifically on the study of ICT but other subjects. This shows that studies are still needed in terms of parents' income level and students' satisfaction and performance in ICT and related subjects. The aim of this study was to fill the gap in the area of satisfaction with ICT as being dependent on parents' income level.

\section{Education Level and Students' Satisfaction with the Study of ICT}

Studies indicated that students' education level determine their satisfaction with ICT studies. In a report, there was a substantial gap between students' satisfaction ratings; first-year students were more pleased with ICT education than fourth-year students (Tatli et al., 2011). One of the results of a study at Dire Dawa University in Ethiopia found little difference in the satisfaction of undergraduate and postgraduate students with the university's operation, including the provision of ICT services (Daniel et al, 2017). The kind of academic programmes students engaged in influenced their satisfaction; therefore, education programmes in school portrays various levels of education in the school (El-Hilali et al., 2017). There seems to be a paucity of research literature on this area. Much is needed to reveal the links between students' education level and their satisfaction with study of ICT, a divide the present was designed to address.

\section{School Location and Students' Satisfaction with the Study of ICT}

Among the results, it was shown that geographical location was not a significant predictor of students' performance (Considine \& Zappa, 2002). The result of a study indicated that students of urban areas performed academically better than their counterparts in the rural schools; the distance that some students take to their school caused lateness to school (Alordiah et al., 2015). Location of school far away from the students led to mass failure, as well as, drop out of the affected students (Mhiliwa, 2015). A study showed scientifically that there was a considerable difference in the average achievement score of students in urban and rural school areas; moreover, there was no large variation in the academic achievement of boys and girls in rural areas (Awodun, 2018).

The result of another empirical study indicated that school location has no significant influence on students' academic achievement (Essien, 2017). While no major gaps were identified, a suggestion was made that the divide between urban and rural schools in the provision of teaching and learning facilities be bridged by stakeholders. The outcome of another study is that students in urban areas had higher academic performance than their rural counterparts (Owoeye \& Yara, 2011). Similarly, another study noticed a huge disparity between the achievement of science and mathematics students in urban and rural schools in favour of urban students (Musa \& Samuel, 2019). In order to bridge the gap between students' academic achievement in rural and urban secondary schools, the researchers recommended that the government ensure the provision of the requisite facilities to enhance the academic success of students in rural areas.

\section{Contribution of the Study}

The literature, specifically on socio-demographic factors and satisfaction with the study of ICT in secondary schools is relatively scarce. Majority of the previous studies reviewed mainly focused on students' academic performance, achievement and outcome as general concepts or constructs in the dependent variable. Emphasis was not on the specific dimension(s) like performance in or satisfaction with ICT study except mostly in Mathematics and science subjects. Also, the bulk of the previous studies (local and foreign) were conducted in tertiary institutions. This justifies the need for the present study to be conducted at the secondary education level. The present study appears to be novel in bridging the gap in knowledge concerning the effects of socio-demographic factors and students' satisfaction with the study of ICT in secondary schools. In contemporary society, where ICT is pervasive, it is crucial to $x$-ray the satisfaction levels of secondary school students towards its study, since it has implications on their performance in the subject in the short- or long-run. Thus, this study specifically sought to find out:

1. the influence of age on students' satisfaction with the study of ICT in secondary schools;

2. gender differences in students' satisfaction with the study of ICT in secondary schools;

3. parents' income level and students' satisfaction with the study of ICT in secondary schools;

4. students' education level and their satisfaction with the study of ICT in secondary schools;

5. the influence of school location on students' satisfaction with the study of ICT in secondary schools.

6. the interactive effect of age, gender, parents' income level, students' education level and school location on students' satisfaction with the study of ICT in secondary schools. 


\section{MATERIALS AND METHODS}

This study adopted a survey research design, to obtain data from students regarding their satisfaction with the study of ICT in secondary schools. The area of study is Calabar Metropolis, Cross River State, Nigeria. The Calabar Metropolis is made up of Calabar Municipality and Calabar South Local Government areas. The former has 16 public secondary schools while the latter has eight public secondary schools, making a total of 24 public secondary schools in the area. The population of the study comprised 4,484 senior secondary school students in the area of study. The sample consisted of 2242 senior secondary students (representing $50 \%$ of the population). The sample was drawn through the simple random sampling technique. The respondents were $48.7 \%$ (N $=1092)$ males and $51.3 \%(\mathrm{~N}=1150)$ female. Most of the respondents $(27.1 \%, \mathrm{~N}=609)$ are less than 12 years old; $24.1 \%(\mathrm{~N}=552)$ were between $12-15$ years; $241 \%(N=540)$ are age between $17-21$ years; while those 21 years and above were $24.1 \%(N=541)$. In terms of educational level, a higher percentage of respondents were in SS2 (34.1\%, N = 765), followed by those in SS1 ( $33.5 \%, \mathrm{~N}=$ $750)$ and SS3 $(32.4 \%, N=727)$. A higher number of students were in urban schools $(35.5 \%, N=795)$ followed by those in rural schools (32.6\%, $\mathrm{N}=731$ ) and sub-urban schools (31.9\%, $\mathrm{N}=716)$.

Data were collected using an instrument constructed by the researchers and titled "Secondary School Students' Satisfaction with the Study of ICT Questionnaire (SSSSSICTQ)". The instrument contained two sections, A and B. Section A was designed to collect data on the demographic variables of respondents such as age, gender, parents' income level, students' educational level and school location. Section B contained 15 items that were designed to measure students' satisfaction with the study of ICT. All the 15 items were organised on a modified six-point Likert scale, with response options including 'extremely satisfied', 'very satisfied', 'satisfied', 'unsatisfied', 'very unsatisfied', and 'extremely unsatisfied.'

To ensure that the instrument was capable of measuring intended constructs (validity), the first draft of the SSSSSICTQ was presented to five experts (Three psychometrists and two educational technology experts) to scrutinize for clarity, relevance and vagueness of items. An initial pool of 24 items was presented to these experts to indicate those they consider very relevant. The Item Content Validity Index (I-CVI) of the instrument was determined by adding the number of validators who ticked each item as being "very relevant" and "very clear" respectively. Doing this, 9 items with I-CV indices below 0.5 were considered as very irrelevant and as such, eliminated from the second draft of the instrument. The other 15 items had I-CVIs which ranged from .79 to .93 , leading to their retention in the second draft of the instrument. During the second round, the assessors were interested in modifying items with high relevance indices but that were not clear. The five experts further scrutinized the second draft of the instrument for clarity and made suggestions that were useful in developing the final of the instrument, which was used for data collection. The reliability of the instrument was ascertained through a trial-test involving 50 senior secondary school students in Calabar Metropolis. These respondents in the pilot study were part of the population but not the sample, hence, they shared similar attributes as those in the sample. Cronbach alpha reliability method was applied on the 15 items in section B of the SSSSICTQ, to check for the internal consistency of the instrument. A coefficient of .89, which was obtained after the reliability analysis, indicated that the instrument was internally consistent and fit for measurement purposes.

The administration of the instrument was undertaken by the researchers with the help of five trained research assistants. Before administering the instruments to the sampled respondents in the schools, a letter of authorization was obtained from the Director of Academic Planning (DAP), as well as Ethical Clearance from the Research Ethics Committee, all in the university of Calabar, Calabar, Nigeria. Permission was also obtained from the principals of the public secondary schools to enable the researchers gain access to the schools for the administration of the instrument. All respondents voluntarily participated in the study after the researchers had explained the implications of participation and how collected data shall be aggregated, used, stored, kept in confidence and shredded when the research is over. Collected data were coded and prepared on a person-by-item matrix and analysed using descriptive statistics, while inferential statistics such as independent t-test, one-way analysis of variance (ANOVA) and the univariate linear model were employed to test the hypotheses formulated (where applicable). These statistical methods were employed because the collected data met the assumptions for their application such as independent categories, a continuous dependent variable, normality (tested using box plots, histogram and Q-Q Plots in Figures 1 to 3), and absence of outliers. The Shapiro-Wilk's Test revealed that the data was normally distributed in the sample $(W=.997, \mathrm{df}=2242, \mathrm{p}$ $=.071>.05)$. 


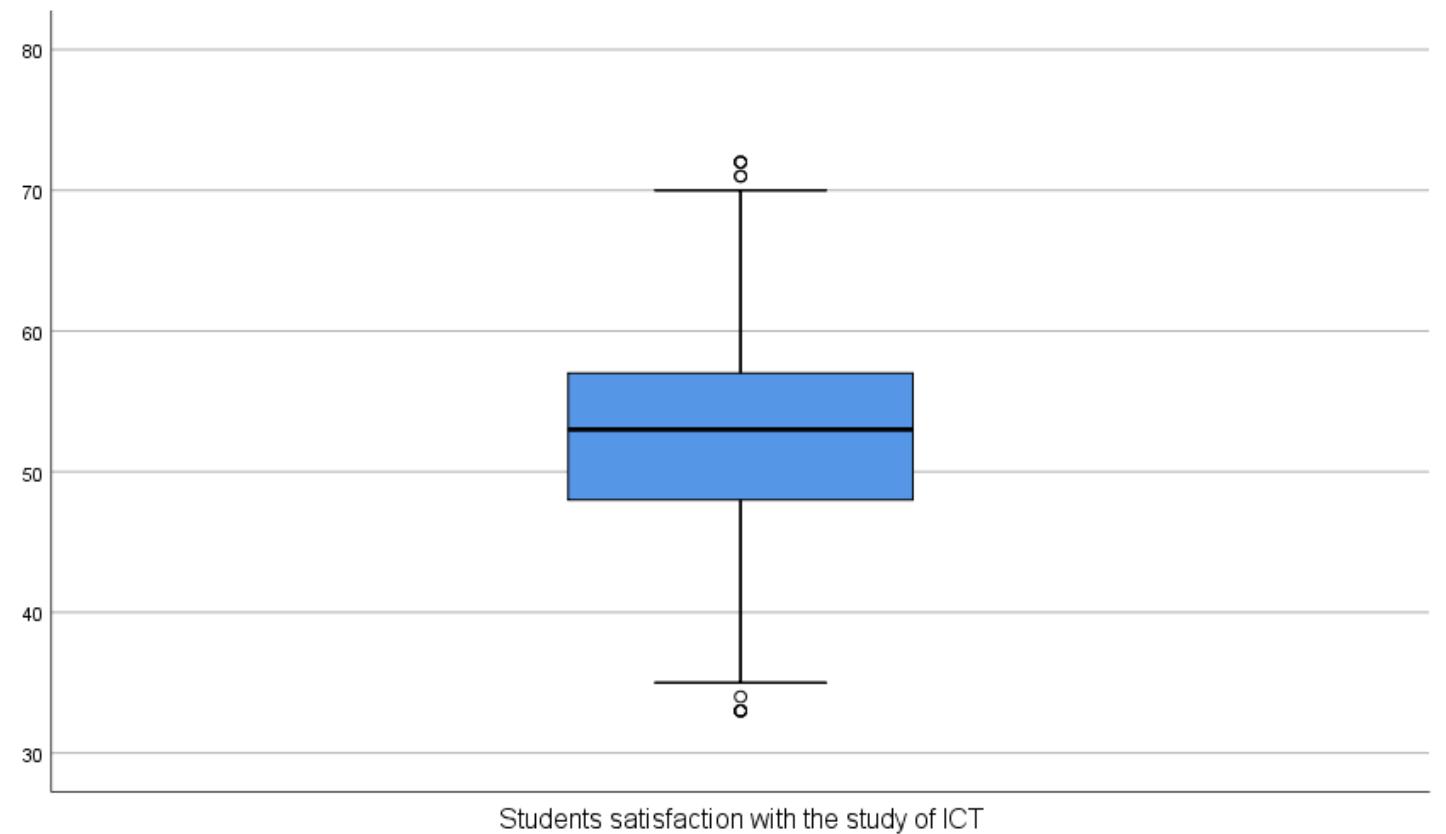

Figure 1. Box plot of students' satisfaction with the study of ICT in secondary schools

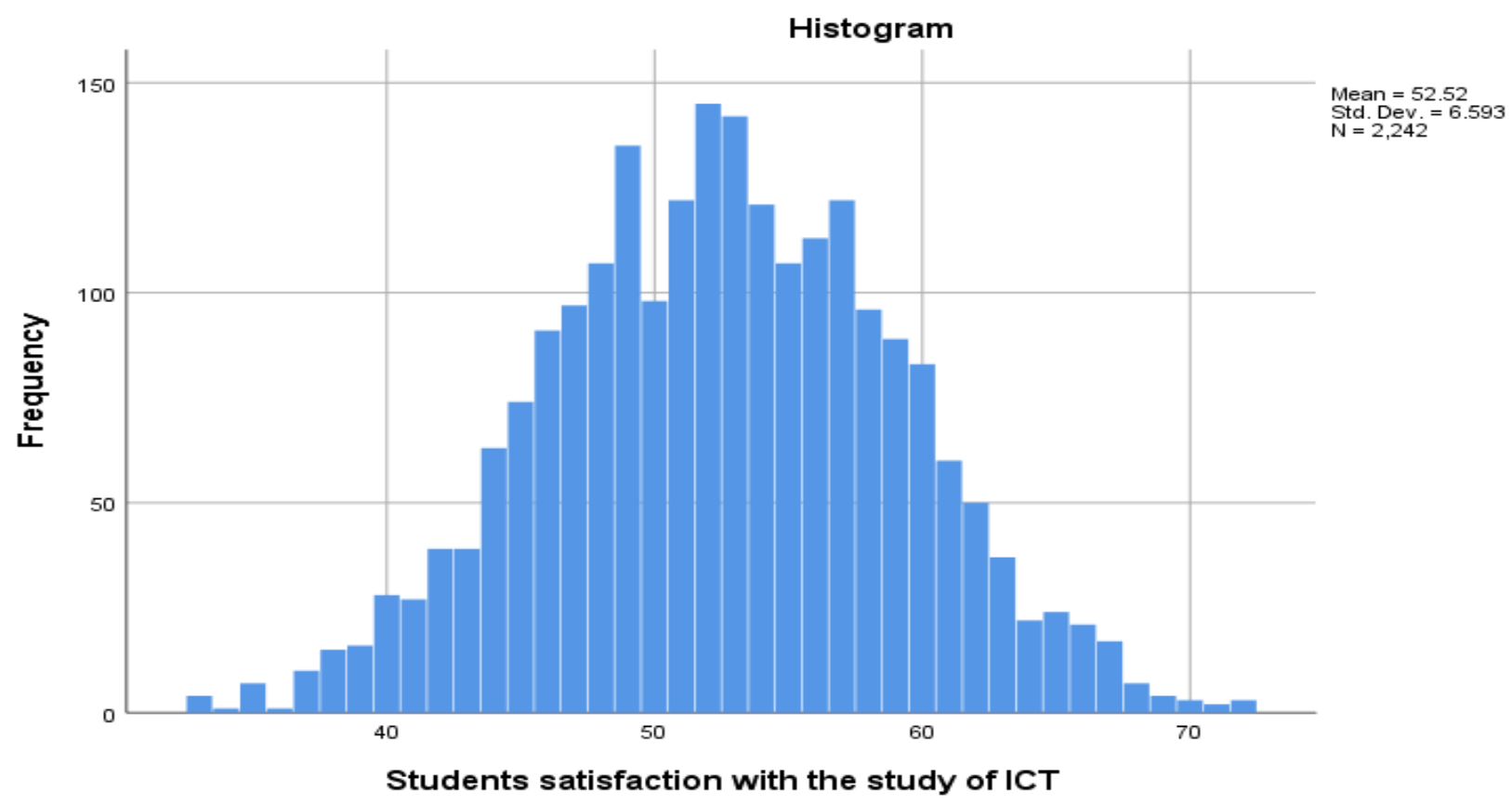

Figure 2. Histogram showing the distribution of students' satisfaction with the study of ICT 


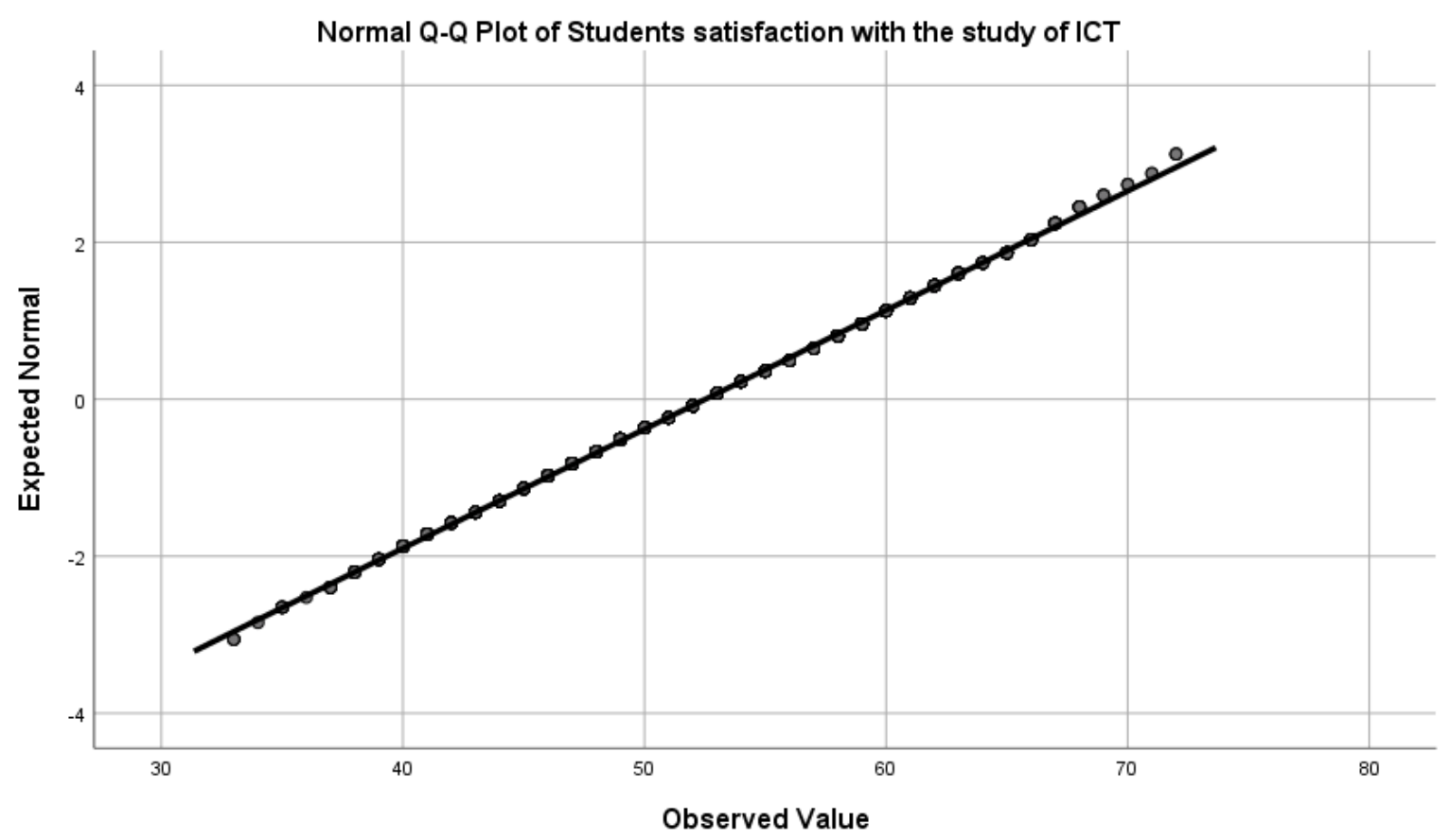

Figure 3. Normal Q-Q plots of students' satisfaction with the study of ICT in secondary schools

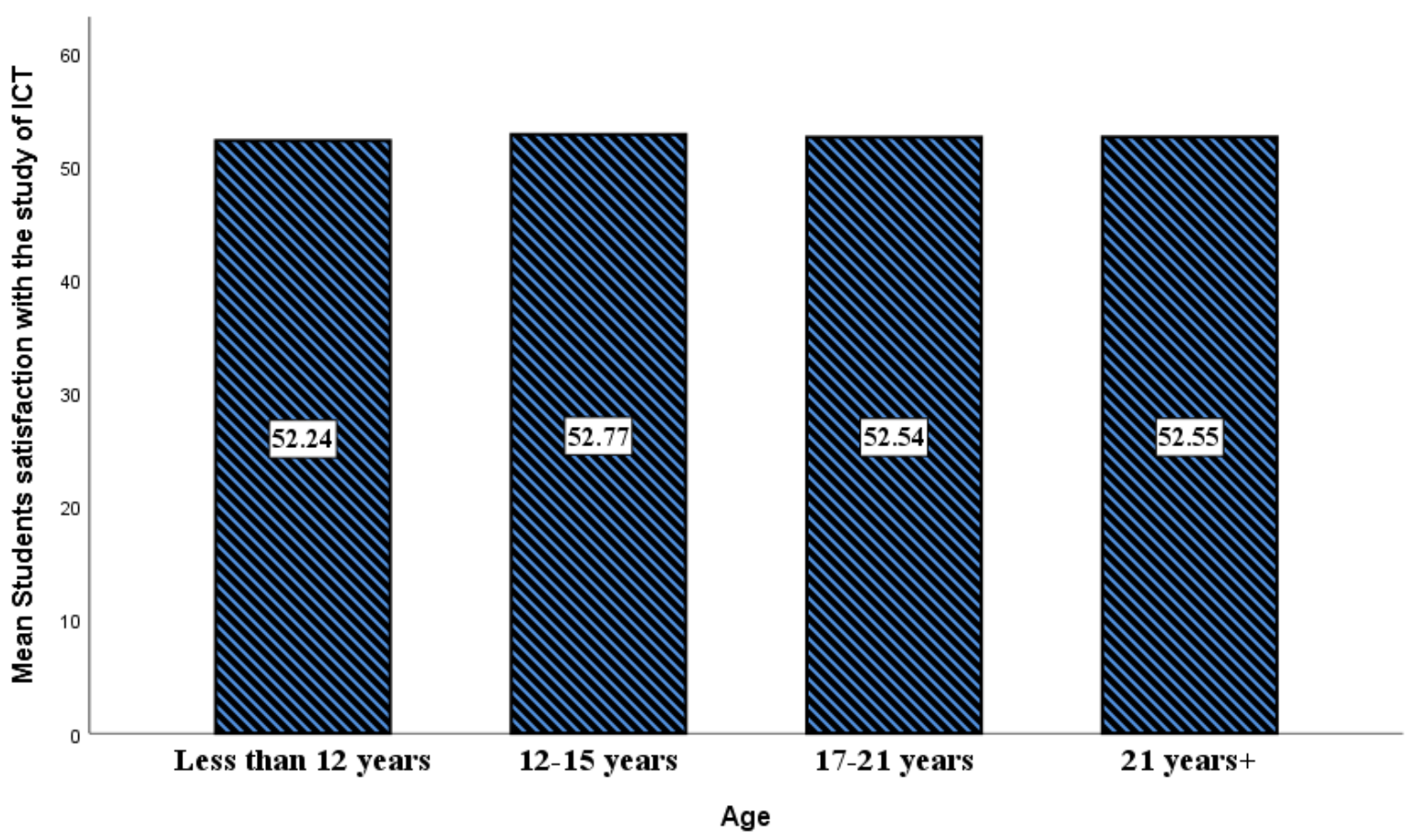

Figure 4. Age and students' satisfaction with the study of ICT in secondary schools

\section{RESULTS}

\section{Hypothesis One}

Students' age has no significant influence on their satisfaction with the study of ICT in secondary schools. This hypothesis was tested at the .05 alpha level using the one-way analysis of variance to compare students' satisfaction with the study of ICT across various age levels. The result of the analysis revealed no significant age variation in students' satisfaction with the study of ICT in secondary schools $\{\mathrm{F}(3,2238)=0.628, \mathrm{p}=.597\}$. Based on this result, the null hypothesis that "students' age has no significant influence on their satisfaction with the study of ICT in secondary schools" was retained. Although no significant variation was recorded based on students' age, the result of the analysis revealed that students between 12 and 15 years were more satisfied (Mean $=52.77, \mathrm{SD}=6.64$ ) with the study of ICT than those 21 years and above (Mean $=52.55, \mathrm{SD}=6.32)$. Students 12 years old or younger, were the least satisfied (Mean $=52.24, S D=6.67$ ) with the study of ICT, followed by those between 17 and 21 years (Mean $=52.54, \mathrm{SD}=6.73)$. This is illustrated graphically in Figure 4. 


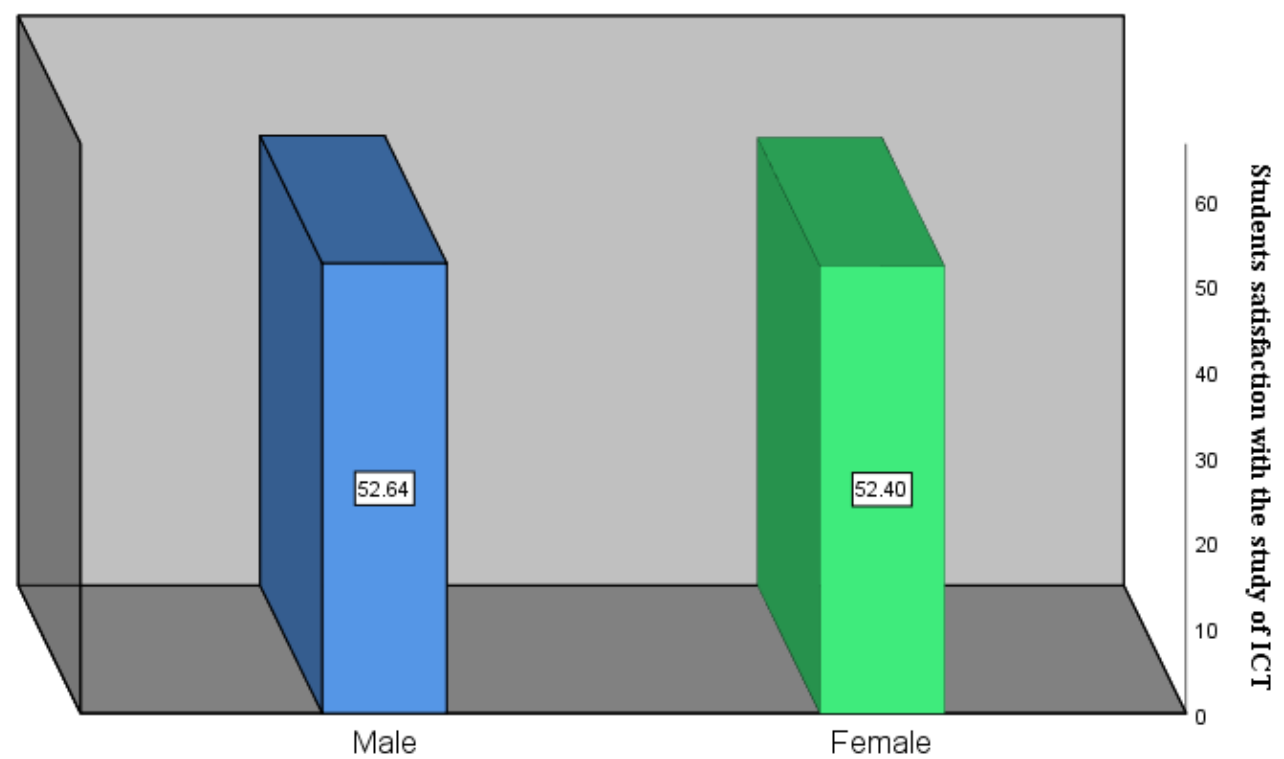

Gender

Figure 5. Gender and students' satisfaction with the study of ICT in secondary schools

\section{Hypothesis Two}

The second hypothesis states that there is no significant gender difference in students' satisfaction with the study of ICT in secondary schools. This hypothesis was tested using the independent t-test statistical technique at the .05 level of significance. At 2240 degrees of freedom, the null hypothesis was retained because the result showed that gender does not significantly influence students' satisfaction with the study of ICT in secondary schools $(t=.875, p=.382)$. Notwithstanding the insignificance of the results, it was discovered that male students showed a higher level of satisfaction (Mean $=52.64, \mathrm{SD}=6.55$ ) with the study of ICT in secondary schools than females (Mean $=52.40, \mathrm{SD}=6.64$ ), as shown in Figure 5.

\section{Hypothesis Three}

Parents' income level does not influence significantly students' satisfaction with the study of ICT in secondary schools. In testing this null hypothesis, parents' income levels were grouped into four levels/categories (low-, average-, high- and very highincome levels). The one-way analysis of variance was employed to test the null hypothesis at the .05 alpha level. It was revealed that parents' income level does not influence significantly students' satisfaction with the study of ICT in secondary schools $\{\mathrm{F}$ ( 3 , $2238)=0.181, p=.909\}$. Hence, the null hypothesis was upheld. Comparatively, students with low parents' income level were more satisfied (Mean $=52.65, \mathrm{SD}=6.69)$ with the study of ICT than those with average (Mean $=52.59, \mathrm{SD}=6.42)$, high $($ Mean $=52.45, \mathrm{SD}$ $=6.58$ ) and very high (Mean $=52.39, \mathrm{SD}=6.701$ ) parents' income levels. This is illustrated graphically in Figure 6 , which suggest that students' satisfaction with the study of ICT is a decreasing function of their parents' income level.

\section{Hypothesis Four}

Students' education level has no significant influence on their satisfaction with the study of ICT in secondary schools. Students' educational level was classified based on the three senior secondary classes (SS1, SS2 and SS3), with the aim of comparing students' satisfaction across these classes. One-way analysis of variance was adopted to compare the means and test the null hypothesis at the .05 alpha level. The result emerged that there was no significant influence of students' educational level on their satisfaction with the study of ICT in secondary schools $\{F(2,2239)=0.348, p=.706\}$. Based on this evidence, the null hypothesis was retained against its corresponding alternate hypothesis. Despite the result, it was however, revealed that students in SSI were more satisfied (Mean $=52.63, \mathrm{SD}=6.52$ ) with the study of ICT in secondary schools than those in SS3 $($ Mean $=52.57, \mathrm{SD}=6.58)$, while those in SS2 were the least satisfied (Mean $=52.36, \mathrm{SD}=6.68$ ). This is illustrated graphically in Figure 7.

\section{Hypothesis Five}

Secondary school students' satisfaction with the study of ICT does not differ significantly based on school location. School location in this context, was classified into urban, suburban and rural, based on the school site. Students were sorted based on this school parameter and grouped accordingly, taking into consideration their satisfaction with the study of ICT. One-way analysis of variance was used to compare the mean satisfaction rate across the three groups. It was revealed that school location does not significantly influence students' satisfaction with the study of ICT in secondary schools $\{F(2,2239)=0.181, p=.835\}$. Therefore, the null hypothesis earlier formulated was retained at the expense of its corresponding alternate hypothesis. Despite the nonsignificance in the mean differences across the various groups, the result indicated, however, that students in suburban schools 


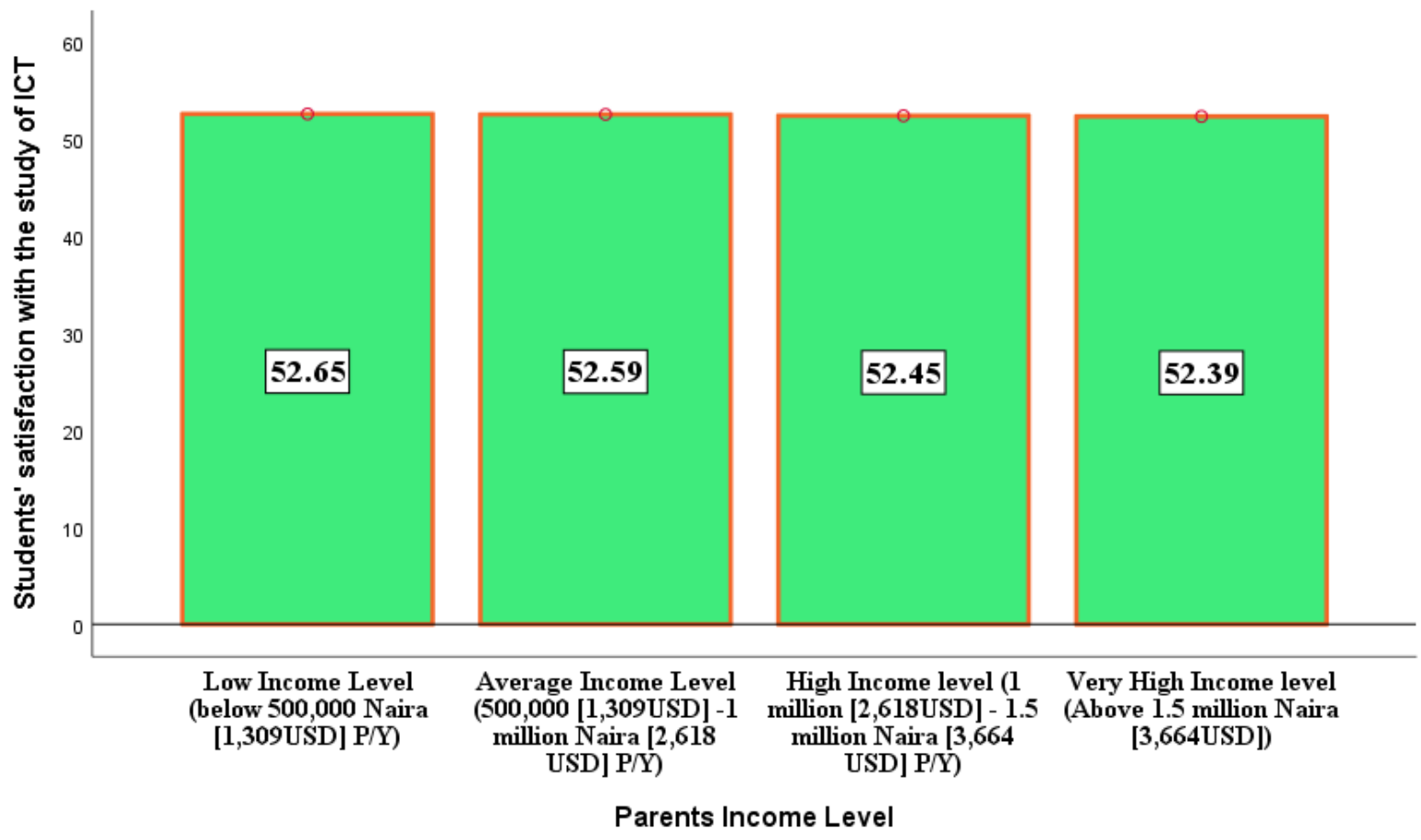

Figure 6. Parents' income level and students' satisfaction with the study of ICT in secondary schools

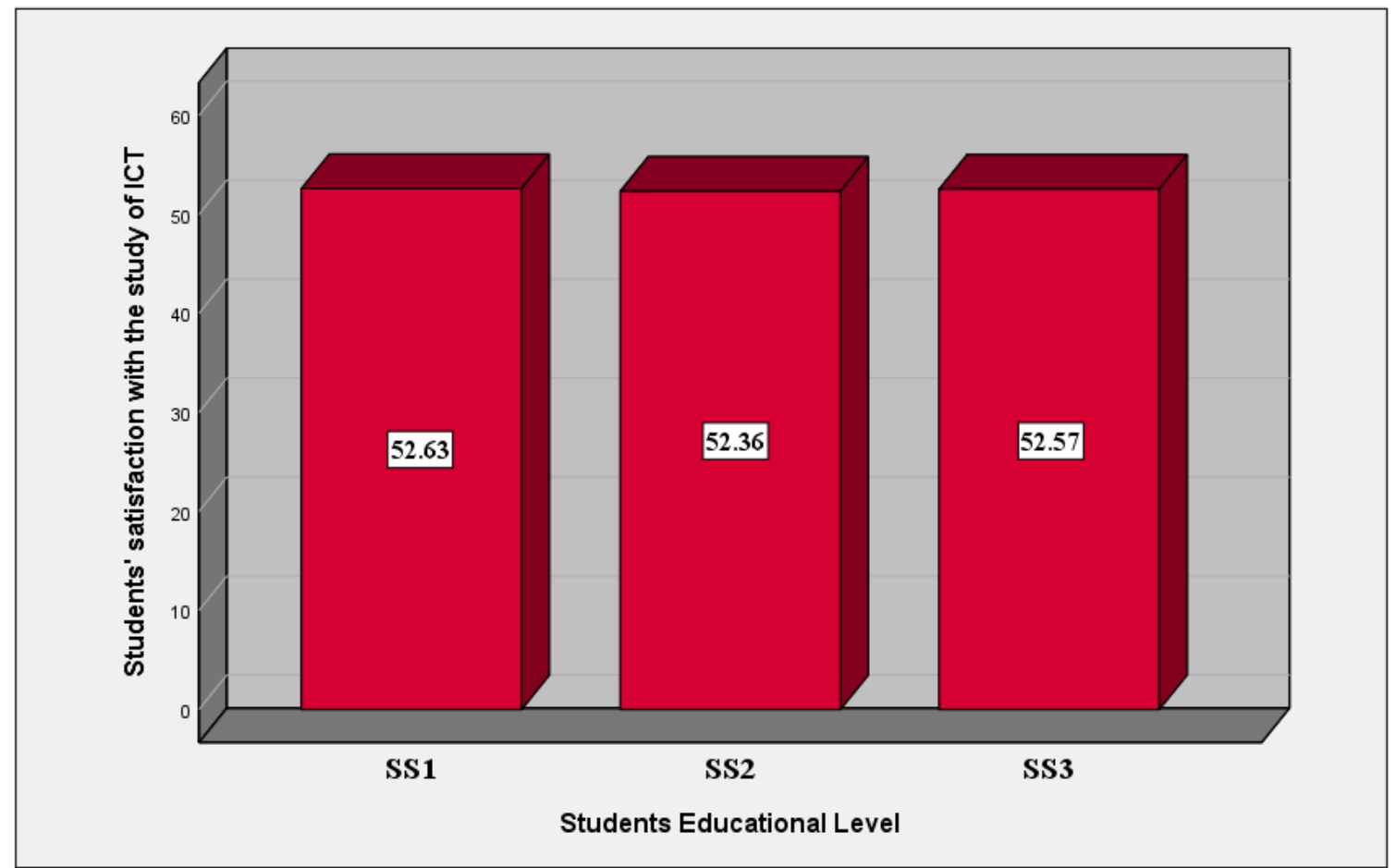

Figure 7. Students' educational level and satisfaction with the study of ICT in secondary schools

were the most satisfied (Mean $=52.60, \mathrm{SD}=6.56)$ with the study of ICT in secondary schools than those in rural schools (Mean $=$ $52.56, \mathrm{SD}=6.64$ ). Students in urban areas were the least satisfied (Mean $=52.41, \mathrm{SD}=6.59$ ) with the study of ICT in secondary schools. For clarity, this has been depicted in Figure 8. 


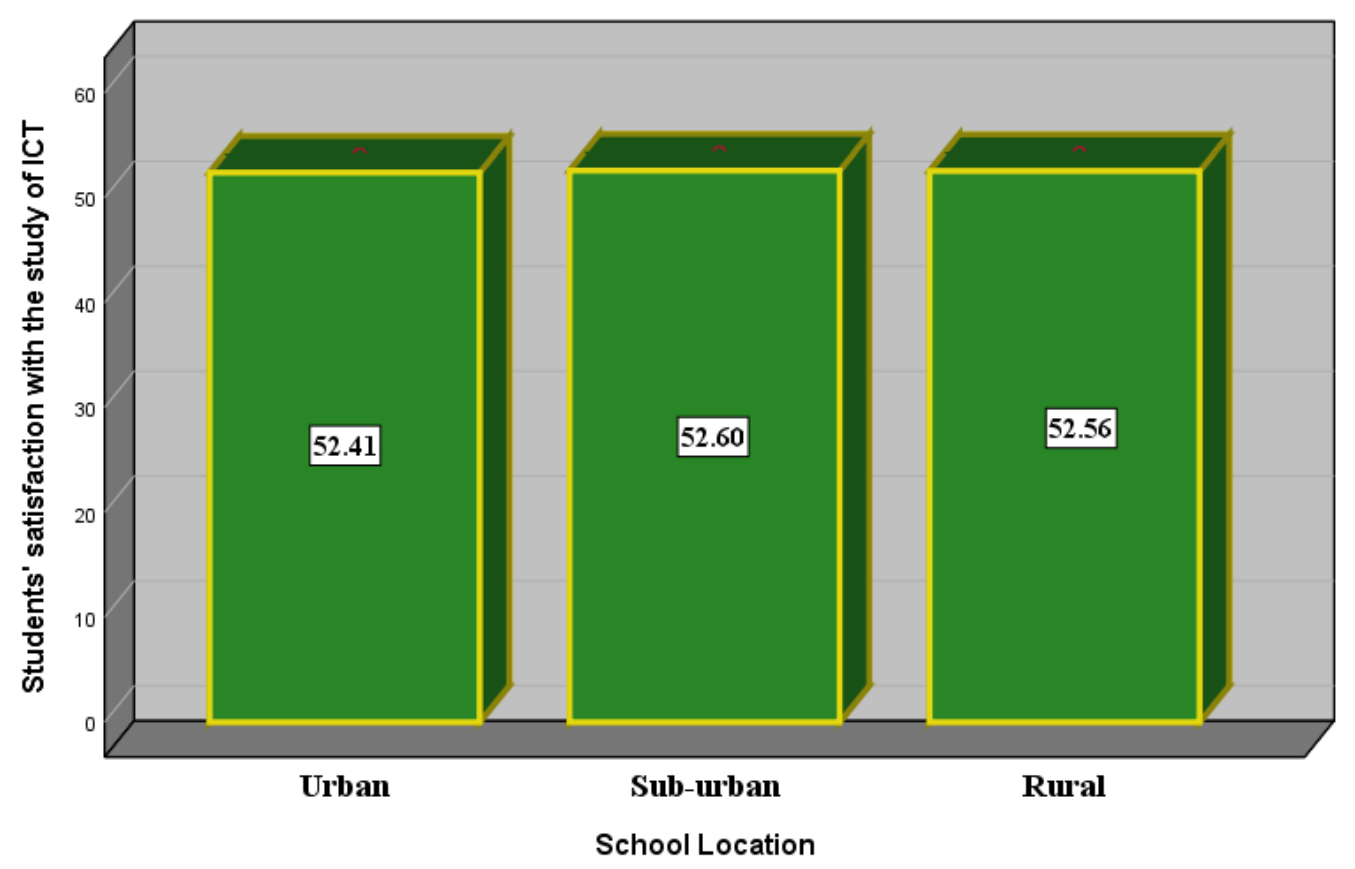

Figure 8. School location and students' satisfaction with the study of ICT in secondary schools

\section{Hypothesis Six}

The sixth null hypothesis states that there are no significant interactive effects of age, gender, parents' income level, students' education level and school location on students' satisfaction with the study of ICT in secondary schools. To test this hypothesis, various interactions were performed using the univariate linear model was used to build the various interaction terms (such as age by gender, age by parents income level, age by students' education level, age by school location, gender by parents income level, gender by students' education level, gender by school location, parents income level by students' education level, parents income level by school location, students' educational level by school location, age by gender by parents income level, age by gender by students' education level, age by gender by school location, age by parents income level by students educational level, age by parents income level by school location, age by students educational level by school location, and the full interactive effect of age, gender, parents income level, students education level and location). Results presented in Table 1, showed that, at the .05 alpha level that none of the interactive terms had a significant effect on students' satisfaction with the study of ICT in secondary schools. Based on this result, the null hypothesis was upheld while the alternate hypothesis was discarded. In any case, at the $90 \%$ confidence level ( $\alpha .=10$ alpha level), only the interaction of age and school location, and the interaction of age, gender and school location had a significant effect on students' satisfaction with the study of ICT.

Table 1. Interactive effects of various terms on students' satisfaction with the study of ICT in Secondary schools

\begin{tabular}{|c|c|c|c|c|c|c|}
\hline Source & Type III SS & Df & MS & $\mathrm{F}$ & Sig. & Partial $\eta^{2}$ \\
\hline Corrected Model & $11846.45^{\mathrm{a}}$ & 287 & 41.28 & .94 & .74 & .122 \\
\hline Intercept & 5250012.70 & 1 & 5250012.70 & 119879.83 & .00 & .984 \\
\hline Age * Gender & 171.20 & 3 & 57.07 & 1.30 & .27 & .002 \\
\hline Age * PIL & 306.18 & 9 & 34.02 & .78 & .64 & .004 \\
\hline Age $^{*}$ SEL & 109.17 & 6 & 18.20 & .42 & .87 & .001 \\
\hline Age $^{*} \mathrm{SL}$ & 483.59 & 6 & 80.60 & 1.84 & .09 & .006 \\
\hline Gender * PIL & 188.99 & 3 & 63.00 & 1.44 & .23 & .002 \\
\hline Gender * SEL & 43.50 & 2 & 21.75 & .50 & .61 & .001 \\
\hline Gender * SL & 156.49 & 2 & 78.24 & 1.79 & .17 & .002 \\
\hline $\mathrm{PIL}^{*} \mathrm{SEL}$ & 180.70 & 6 & 30.12 & .69 & .66 & .002 \\
\hline $\mathrm{PIL}^{*} \mathrm{SL}$ & 56.49 & 6 & 9.42 & .22 & .97 & .001 \\
\hline$S E L{ }^{*} \mathrm{SL}$ & 48.14 & 4 & 12.04 & .28 & .89 & .001 \\
\hline Age * Gender * PIL & 437.46 & 9 & 48.61 & 1.11 & .35 & .005 \\
\hline Age * Gender * SEL & 195.79 & 6 & 32.63 & .75 & .61 & .002 \\
\hline Age * Gender * SL & 465.41 & 6 & 77.57 & 1.77 & .10 & .005 \\
\hline Age * $\mathrm{PIL}{ }^{*} \mathrm{SEL}$ & 520.10 & 18 & 28.89 & .66 & .85 & .006 \\
\hline Age $^{\star} \mathrm{PIL}^{\star} \mathrm{SL}$ & 877.64 & 18 & 48.76 & 1.11 & .33 & .010 \\
\hline Age * SEL * SL & 381.49 & 12 & 31.79 & .73 & .73 & .004 \\
\hline Age $^{\star}$ Gender ${ }^{\star} \mathrm{PIL}^{*} \mathrm{SEL}{ }^{*} \mathrm{SL}$ & 6584.75 & 160 & 41.16 & .94 & .69 & .071 \\
\hline Error & 85573.41 & 1954 & 43.79 & & & \\
\hline Total & 6280923.00 & 2242 & & & & \\
\hline Corrected Total & 97419.86 & 2241 & & & & \\
\hline
\end{tabular}

a. R Squared = .122 (Adjusted R Squared $=-.007$ ) 


\section{DISCUSSION OF FINDINGS}

This study revealed that age is not a significant factor that affects students' satisfaction with the study of ICT in secondary schools. Although there were differences in students' satisfaction across various age groups, such differences were not deemed to be statistically relevant. The finding may be attributed to students' level of awareness, future career desires or the teaching approach employed by ICT teachers, which may affect the level of interest notwithstanding the age of students. This result support the position held by several studies that the usage of ICT services is not significantly influenced by age (Alba \& Trani, 2018; AmuaSekyi \& Asare, 2016; Mazoya, et al., 2015). While this finding supports the previous studies, it also presents new evidence from the perspective of students regarding their satisfaction with the study of ICT and not the utilization of ICT resources. The finding, however, contradicts the result of some studies which found a significant influence of age on ICT utilization by staff or students (Dei, 2018; Liu \& Haque, 2017; Oluwunmi et al., 2017).

The study also showed that gender among students has no substantial effect on their satisfaction with the study of ICT in secondary schools, while males have shown a higher degree of satisfaction than females. The statistical insignificance of the mean discrepancy between male and female students may be attributed to students' understanding of the value of secondary school ICT studies or other considerations such as the teaching approach used, the attitude of other peers to ICT studies, and so on. These factors may be independent of gender, as people of different sexes hold different or similar views about a phenomenon which could affect their interest or dissatisfaction towards it. Along these lines, studies indicated that learning satisfaction is higher on the part of the males than the female students (Lowerision et al., 2004; Mahdi \& Sa'ad Al-Dera, 2013; Oluwunmi et al., 2017; Yang et al., 2016), but no significant differences were found regarding students' satisfaction with ICT studies based on gender (Dholakia et al., 2013; Mahdi \& Al-Dera, 2013; Tatli et al., 2011). Contrary to this study's finding, gender was shown by a study to have a substantial effect on the usage of ICT tools for record management, teaching and research (Odigwe \& Owan, 2020). Another research documented that there are large disparities between males and females in their satisfaction with the provision of university resources (Akpoiroro \& Okon, 2015). The outcomes of these reports and the outcomes of the present research differed due to the variations in the dependent variable tested, as well as the level of education in question. The present research centred on students' satisfaction with the study of ICT in secondary schools, while previous studies focused on the use of ICT in colleges, as well as on students' satisfaction with the implementation of university facilities. These may be responsible for the different results.

This research also found that the income level of parents is a diminishing function of students' satisfaction with the study of ICT in secondary schools, which does not significantly alter students' satisfaction with the study of ICT. This implies that students from richer parents are less likely to be satisfied with the study of ICT than those from poorer parents. This finding may be attributed to three reasons - first may be the ability of richer parents to procure quality and state-of-the-art ICT infrastructures for their children at home which may be of a standard than those available in schools. Another reason may be attributed to the highinterest level of children from poorer homes to manipulate ICT gadgets in schools which are most often, not available in their homes due to their parents' low-income level. Lastly, children from poor homes tend to show interest and portray positive attitudes towards academic work than those from rich homes, with the hope of changing their socio-economic status in the future. In line with this, a study has shown that although students from low-income backgrounds were able to discover their passion in academics, notwithstanding their parental low income, they were able to succeed academically in school and were also satisfied with their academic achievement (Dias, 2017). This finding agrees with the position of an earlier study which indicated that family income is not a significant predictor of students' academic performance (Considine \& Zappa 2002). Nevertheless, the position of this finding challenges a wide body of studies which tend to reveal that parental income influenced the academic performance of students (Adzido, 2016; Finnie \& Mueller, 2008; Joseph, 2016; Lacour \& Tissington, 2011; Odoh et al, 2017; Owan, 2012). Since the construct "students' academic performance" that was assessed in most of these researches is different from students' satisfaction with the study of ICT, the variation in findings may be taken lightly, with a call placed for further research on parents' income level and students' satisfaction with the study of ICT in secondary schools.

It was also discovered through this study that students' education level does not greatly affect their satisfaction with the study of ICT in secondary schools, although students in the first senior class (SS1) indicated the highest satisfaction rate. This finding may be attributed to the excitement with which students in SSI go into the classroom, perhaps due to the change in status from junior to the senior section of secondary schools. This migration sometimes comes with a change in the pattern of uniforms worn, which usually differs between junior and senior sections of secondary schools. At SS2, students' interest in the study of ICT may have dropped because the excitement in the previous class, tends to drop and the quest to become prefects sets in. In most public secondary schools, SS2 students are in charge of monitoring, controlling and regulating the activities of other students, leading to a high rate of movement around the school with little or no attention towards studies. Students interest to study ICT at this point may drop as many Senior Secondary Class 2 (SS2) students are rather carried away by administrative and punitive duties than classroom duties. In SS3 (when power has been taken), an increase was recorded in students' satisfaction with the study of ICT as students are rounding-up their secondary education in preparation for the West African Senior School Certificate Examination, as well as higher education. This finding tallies with the result of another research which indicated that first-year students were more satisfied with ICT education than fourth-year students (Tatli et al., 2011). Among undergraduate and postgraduate students, there was no variation in their satisfaction with the service of the university (Daniel et al., 2017).

It was also discovered in this study that the location of schools has no notable impact on student' satisfaction with the study of ICT in secondary schools, although students in suburban schools were most satisfied with the study of ICT. This is followed by students in rural and urban schools respectively, in that order. An explanation for this may be due to the increased desires among the rural and sub-urban population to become vested in the use of ICT devices. Students in schools located in these regions may 
be very interested in the study of ICT and could derive satisfaction if it is taught effectively. Students in urban schools are more likely to have been exposed to ICT equipment in their homes or from older siblings, some may even be very competent users of such gadgets, reducing their interest and satisfaction levels especially if the teacher is incompetent in teaching the subject. This finding aligns with the result of studies which documented that geographical location was not a significant predictor of the students' performance (Considine \& Zappa, 2002; Essien, 2017). Most studies have documented that students of urban schools performed academically better than their counterparts in the rural schools (Alordiah et al., 2015; Mhiliwa, 2015; Musa \& Samuel, 2019; Owoeye \& Yara, 2011). While this study found higher rates of satisfaction among students in schools located in the sub-urban and rural regions, the result is not the same as those of studies focusing on academic performance based on school location.

\section{CONCLUSION}

It may be concluded that socio-demographic characteristics do not affect overall students' satisfaction with the study of ICT in secondary schools. Even though differences were observed in the satisfaction of students to study ICT based on different groupings in demographic factors, the mean differences are not remarkably substantial and are negligible. Therefore, if there are notable variations in the satisfaction of students to study ICT at the secondary education level, it may not have resulted from factors such as their age, gender and educational level, income level of parents and the location of school. This study has implications on the extent to which ICT tools will be utilized in the future for teaching and learning. Teachers who are not teaching ICT effectively may command little or no satisfaction from students which potentially affect future learning outcomes. The study has also provided a basis for further studies in areas related to this for both ground-breaking and/or validation purposes. However, the study faces a limitation due to the small area of geography covered, which affects the extent or confidence in making generalisations to the larger population. This gap, therefore, places a call for further studies at the regional, national and crosscountry levels to be conducted in related areas, for more dependable results.

Author contributions: All authors have sufficiently contributed to the study, and agreed with the results and conclusions.

Funding: No funding source is reported for this study.

Declaration of interest: No conflict of interest is declared by authors.

\section{REFERENCES}

Adzido, R. Y. N., Dzogbede, O. E., Ahiave, E., \& Dorkpah, O. K. (2016). Assessment of family income on academic performance of tertiary students: The case of Ho Polytechnic, Ghana. International Journal of Academic Research in Accounting, Finance and Management Sciences, 6(3), 154-169. https://doi.org/10.6007/IJARAFMS/v6-i3/2221

Agyemang, M., Hagan, E., \& Agyabeng, S. (2019). Technology use among Ghanaian Senior High School students' in learning mathematics and the factors that influence it. African Journal of Educational Studies in Mathematics and Sciences, $15,77-87$. https://doi.org/10.4314/ajesms.v15i1.7

Aitokhuehi, J. O., \& Ojogho, J. (2014). The impact of computer literacy on students' academic performance in secondary schools in Esan West Local Government Area, Edo State, Nigeria. Journal of Education and Human Development, 3(3), 265-270. https://doi.org/10.15640/jehd.v3n3a21

Akomolafe, C. O. (2008). The use of Information Communication Technology (ICT) in secondary schools in Nigeria: Challenges and prospects. In J. B. Babalola, G. O. Akpa, I. Hauwa \& A. O. Ayeni (Eds.), Managing education for sustainable development in developing countries (277-282). His Lineage Publishing House NAEP Publication.

Akpoiroro, R. M., \& Okon, J. E. (2015). Students' gender and their satisfaction with service delivery in Federal Universities in SouthSouth Nigeria. Advances in Social Sciences Research Journal, 2(4), 54-59. https://doi.org/10.14738/assrj.24.1061

Alba, A. B., \& Trani, L. C. (2018). Extent of utilization of Information and Communication Technology (ICT) by selected secondary school teachers of City Schools Division of Malolos: Basis for the development of a strategic action plan. International Journal of Education and Research, 6(1), 181-188. https://tinyurl.com/txhy8ep

Alcántar, M., Islas Torres, C., Montes, J., Jiménez, A., \& Alcaraz, D. (2017). The use of ICT by high school students and the impact on academic performance. International Technology, Education and Development Conference, $2428-2436$. https://doi.org/10.21125/inted.2017.0688

Alkhateeb, M. A., \& Abdalla, R. A. (2021). Factors influencing student satisfaction towards using learning management system Moodle. International Journal of Information and Communication Technology Education (IJICTE), 17(1), $138-153$. https://doi.org/10.4018/IJICTE.2021010109

Alordiah, C. O., Akpadaka, G., \& Oviogbodu, C. O. (2015). The influence of gender, school location and socio-economic status on students' academic achievement in Mathematics. Journal of Education and Practice, 6(17), $130-136$. https://files.eric.ed.gov/fulltext/EJ1079759.pdf

Aluko, S. A. (2012). Relevance of ICT in school management. Journal of Information Management, 3(1), 16-28.

Amenyedzi, F. W. K., Lartey, M. N., \& Dzomeku, B. M. (2011). The use of computers and internet as supplementary source of education. A case study of the senior secondary schools in the Tema Metropolis in Ghana. Contemporary Educational Technology, 2(2), 151-162. https://doi.org/10.30935/cedtech/6049 
Amro, H. J., Mundy, M., \& Kupczynski, L. (2015). The effects of Age and Gender on student achievement in face-to-face and online college algebra classes. Research in Higher Education Journal, 27, 1-22. https://www.aabri.com/manuscripts/142077.pdf

Amua-sekyi, E. T., \& Asare, P. Y. (2016). A survey of Information Communication Technology literacy among lecturers. Journal of Education and Practice, 6(8), 1-7. https://tinyurl.com/vs6pbj6

Anumnu, S. I. (2008). Information and Communication Technology for Sustainable Classroom Management. In J. B. Babalola, G. O. Akpa, I. Hauwa \& A. O. Ayeni (Eds.), Managing education for sustainable development in developing countries (pp. 283-289). His Lineage Publishing House NAEP Publication.

Awodun, A. O., \& Oyeniyi, A. D. (2018). Influence of school location on students' academic achievement in junior secondary school basic science in Ekiti State, Nigeria. Journal of Emerging Technologies and Innovative Research (JETIR), 5(6), 125-129. http://www.jetir.org/papers/JETIR1806519.pdf

Bauk, S., Šćepanović, S., \& Kopp, M. (2014). Estimating students' satisfaction with web based learning system in blended learning environment. Education Research International, 2014, 731720. https://doi.org/10.1155/2014/731720

Considine, G., \& Zappa, G. (2002). The influence of social and economic disadvantage in the academic performance of school students in Australia. Journal of Sociology, 38(2), 129-148. https://doi.org/10.1177/144078302128756543

Daniel, D., Liben, G., \& Adugna, A. (2017). Assessment of students' satisfaction: A case study of Dire Dawa University. Ethiopia. Journal of Education and Practice, 8(4), 111-120. https://files.eric.ed.gov/fulltext/EJ1133033.pdf

Dei, D.-G. J. (2018). Assessing the use of Information and Communication Technology in teaching and learning in secondary schools. Library Philosophy and Practice, 1-17. http://digitalcommons.unl.edu/libphilprac/2003

Dholakia, R. R., Dholakia, N., \& Kshetri, N. (2013). Gender and Internet usage. In H. Bidgoli (Ed.), The Internet encyclopaedia. Wiley.

Dias, P. R. (2017). The experience of low-income college students at a selective university: An interpretative phenomenological analysis (Unpublished Doctoral Thesis, College of Professional Studies, Northeastern University, Boston, Massachusetts).

Dibbon, D. C., \& Pollock, K. (2007). The nature of change and innovation in five innovative schools. The Innovation Journal: The Public Sector Innovation Journal, 12(1), 25-28.

Ekpoh, U. I., \& Asuquo, M. E. (2018). Management techniques and sustainability of post-basic education in Calabar Education Zone of Cross River State, Nigeria. African Journal of Studies in Education, 12(2), $39-53$.

Ekpoh, U. I., Edet, A. O., \& Ekanem, E. E. (2013). Students' perception of information and communication usage in the University of Calabar. Journal of Education, 4(1), 264-274.

El-Hilali, N., Al-Jaber, S., \& Hussein, L. (2014). Students' satisfaction and achievement and absorption capacity in higher education. Procedia - Social and Behavioral Sciences, 77, 420-427. https://doi.org/10.1016/j.sbspro.2015.02.384

Essien, E. E. (2017). Influence of school location on students' academic achievement in social studies in Colleges of Education in Cross River State, Nigeria. Journal of Research in Science and Technology, 7(2), 1-16.

Faisal, P., \& Kisman, Z. (2020). Information and communication technology utilization effectiveness in distance education systems. International Journal of Engineering Business Management. https://doi.org/10.1177/1847979020911872

Federal Republic of Nigeria (2014). National Policy on Education. NERDC Press.

Finani, F. (2012). Information and Communication Technology in a globalized society. Journal of Science and Computer Research, 2(2), 19-31.

Finnie, R., \& Mueller, R. E. (2008). The effect of family income, parental education and other background factors on access to postsecondary education in Canada. A MESA Project Research Paper. https://bit.ly/3qntjh3

Fraillon, J., Ainley, J., Schulz, W., Friedman, T., \& Gebhardt, E. (2014). Students' use of and engagement with ICT at home and school. In J. Fraillon, J. Ainley, W. Schulz, T. Friedman, \& E. Gebhardt (Eds.), Preparing for Life in a Digital Age (pp. 125-166). Springer International Publishing. https://doi.org/10.1007/978-3-319-14222-7_6

Goyal, E., \& Purohit, S. (2011). Using moodle to enhance students satisfaction from ICT. 2011 IEEE International Conference on Technology for Education, 191-198. https://doi.org/10.1109/T4E.2011.37

Himat, A. N., Takal, M. H., \& Hakimi, M. F. (2021). Afghan students' satisfaction from online learning during covid-19 at Kandahar University, Kandahar, Afghanistan. American International Journal of Social Science Research, 6(1), 16-29. https://doi.org/10.46281/aijssr.v6i1.931

Jegede, P. O. (2009). Age and ICT-related behaviours of higher education teachers in Nigeria. Issues in Informing Science and Information Technology, 6, 771-777. https://bit.ly/3aojMAH

Joel, I. E., Ogi, J., \& Ikpe, J. (2019). Politics of ICT integration in secondary schools in Nigeria: Problems and prospects. BSUJEM, $1(2), 250-260$.

Joseph, V. I. (2016). Relationships among parents' educational level, income, academic adjustment and performance of senior secondary school students in Kaduna Metropolis, Nigeria (Unpublished M.Ed. Dissertation, Ahmadu Bello University, Zaria Nigeria).

Khadijatu, M. (2017). Gender difference in math anxiety and mathematics performance of secondary schools' students in Bauchi State Nigeria. International Journal of Education and Evaluation, 3(11), 26-31.

Lacour, M., \& Tissington, L. D. (2011). The effects of poverty on academic achievement. Educational Research and Reviews, 6(7), 522527. 
Lindberg, S. M., Hyde, J. S., Petersen, J. L., \& Linn, M. C. (2010). New trends in gender and mathematics performance: A metaanalysis. Psychol Bull., 136(6), 1123-1135. https://doi.org/10.1037/a0021276

Liu, L., \& Haque, M. D. (2017). Age difference in research course satisfaction in a blended Ed.D. Program: A moderated mediation model of the effects of internet self-efficacy and statistics anxiety. Online Journal of Distance Learning Administration, 20(2), 188445. https://www.learntechlib.org/p/188445/

Lowerision, G., Sclater, J., Schmid, R. F., \& Abrami, P. C. (2004). Students' perceived effectiveness of computer technology use in post-secondary classroom. Computer \& Education, 47(2006), 465-489. https://doi.org/10.1016/j.compedu.2004.10.014

Machebe, C. H., Ezegbe, B. N., Onuoha, J. C. (2017). The impact of parental level of income on students' academic performance in high schools in Japan. Universal Journal of Educational Research, 5(9), 1614-1620. https://doi.org/10.13189/ujer.2017.050919

Mahdi, H. S., \& Al-Dera, A. S. (2013). The impact of teachers' age, gender and experience on the use of information and communication technology in EFL teaching. English Language Teaching, 6(6), 57-67. https://doi.org/10.5539/elt.v6n6p57

Mazoya, A., Ismail, A., \& Manyilizu, M. (2015). Age of teachers vs ICT use in Tanzanian secondary schools: A case of Dodoma Municipality. International Journal of Computer Applications, 132(14), 22-26. https://doi.org/10.5120/ijca2015907579

Mhiliwa, J. A. (2015). The effects of school location on learner's academic performance: A case of community secondary schools in Makambako Town Council, Njombe (M.Ed. Dissertation, Open University of Tanzania).

Moshood, T. D., Nawanir, G., Sorooshian, S., Mahmud, F., \& Adeleke, A. Q. (2020). Barriers and benefits of ICT adoption in the Nigerian construction industry: A comprehensive literature review. Applied System Innovation, 3(46), 1-19.

Musa, D. C., \& Samuel, I. R. (2019). Influence of gender and school location on science and Mathematics Students' achievement in Western Senatorial District of Nasarawa State, Nigeria. East African Scholars Multidisciplinary Bulletin, 2(8), $259-264$. https://doi.org/10.36349/EASMB.2019.v02i08.001

Nzulumike, C., Ahupa, V. I., \& Achugbu, P. C. (2008). Universal Basic Education: A catalyst for sustainable development. In J. B. Babalola, G. O. Akpa, I. Hauwa, \& A. O. Ayeni (Eds.), Managing education for sustainable development in developing countries (pp. 213-220). His Lineage Publishing House NAEP Publication.

Odigwe, F. N., \& Owan, V. J. (2020). Academic staff personal variables and utilization of ICT resources for research, teaching and records management in higher education. Proceedings of the 8th Annual European Conference on Education (ECE, 2020), 107123. https://bit.ly/2GG36II

Odoh, L. C., Ugwuanyi, U. B., \& Chukwuani, N. V. (2016). The impact of parental level of income on students' academic performance in High School in Japan. Universal Journal of Educational Research, 5(9), 1614-1620. https://doi.org/10.13189/ujer.2017.050919

Ogunlade, O. O. (2008). Information Communication Technology in Educational Management and Development. In J. B. Babalola, G. O. Akpa, I. Hauwa, \& A. O. Ayeni (Eds.), Managing education for sustainable development in developing countries (pp. 29-294). His Lineage Publishing House NAEP Publication.

Oluwunmi, A. O., Ajibola, M. O., Iroham, C. O., \& Eluye, P. (2017). Students' with major academic facilities in private universities in Ogun State, Nigeria. Covenant University Journal of Business \& Social Sciences (CJBSS), 8(1), 44-59. https://doi.org/10.21125/iceri.2017.1606

Onuma, N. (2007). Utilization of Information Communication Technology (ICT) in schools: Problems and suggestions. In J. B. Babalola, G. O. Akpa, I. Hauwa, \& A. O. Ayeni (Eds.), Access, equity and quality in higher education (pp. 487-496). His Lineage Publishing House NAEP Publication.

Owan, V. J. (2012). Some causes of poor performance of pupils in primary school mathematics. A case study in Akamkpa Local Government Area of Cross River State, Nigeria. In Cross River State College of Education, Akamkpa. https://doi.org/10.2139/ssrn.3221784

Owan, V. J. (2020). Effects of gender, test anxiety and test items scrambling on students' performance in Mathematics: A quasiexperimental study. World Journal of Vocational Education and Training, 2(2), 56-75. https://doi.org/10.18488/journal.119.2020.22.56.75

Owan, V. J., Bassey, B. A., \& Ini, S. E. (2020). Interactive effect of gender, test anxiety, and test items sequencing on academic performance of SS3 students in Mathematics in Calabar Education Zone, Cross River State, Nigeria. American Journal of Creative Education, 3(1), 21-31. https://doi.org/10.20448/815.31.21.31

Owan, V. J., Duruamaku-dim, J. U., \& Eneje, S. (2019). Mode of test administration, birth variables, and students' academic achievement in Mathematics in Obubra Local Government Area of Cross River State, Nigeria. Prestige Journal of Counselling Psychology, 2(2), 60-77. https://bit.ly/2Xfux0D

Owoeye, J. S., \& Yara, P. (2011). School location and academic achievement of secondary school in Ekiti State, Nigeria. Asian Social Science, 7(5), 170-175. https://doi.org/10.5539/ass.v7n5p170

Pérez-Pérez, M., Serrano-Bedia, A. M., \& García-Piqueres, G. (2020). An analysis of factors affecting students' perceptions of learning outcomes with Moodle. Journal of Further and Higher Education, 44(8), $1114-1129$. https://doi.org/10.1080/0309877X.2019.1664730

Rahman, N. A. A., Hussien, N., \& Aluwi, A. H. (2015). Satisfaction on blended learning in a public higher education insitution: What factors matter? Procedia - Social and Behavioural Sciences, 211, 768-775. https://doi.org/10.1016/j.sbspro.2015.11.107 
Salam, M., \& Farooq, M. S. (2020). Does sociability quality of web-based collaborative learning information system influence students' satisfaction and system usage? Int J Educ Technol High Educ, 17(26), 1-39. https://doi.org/10.1186/s41239-020-00189Z

Salikutluk, Z., \& Heyne, S. (2017). Do gender roles and norms affect performance in Maths? The Impact of adolescents' and their peers' gender conceptions on Maths grades. European Sociological Review, 33(3), 368-381. https://doi.org/10.1093/esr/jcx049

Sarfo, F. K., Amankwah, F., \& Konin, D. (2017). Computer self-efficacy among senior high school teachers in Ghana and the functionality of demographic variables on their computer self-efficacy. TOJET: The Turkish Online Journal of Educational Technology, 16(1), 19-31.

Soharwardi, M. A., Fatima, A., Nazir, R., \& Firdous, A. (2020). Impact of parental socioeconomic status on academic performance of students: A case study of Bahawalpur. Journal of Economics and Economic Education Research, 21(2), 2-8.

Suleman, Q., Aslam, H. D., Hussain, I., Shakir, M., \& Nis, Z. (2012). Effects of parental socioeconomic status on the academic achievement of secondary school students in District Karak Pakistan. International Journal of Human Resource Studies, 2(4), 15-32. https://doi.org/10.5296/ijhrs.v2i4.2511

Tatli, Z. H., Kokoc, M., \& Karal, H. (2011). Satisfaction state of computer education and instructional technologies students: Karadeniz Technical University Case. Elementary Education Online, 10(3), 836-849. http://ilkogretim-online.org.tr

Uko, E. S., Mbon, U. F., Okon, J. E., Ebuara, V. O., \& Arop, F. O. (2020). Principals characteristics and the utilization of internet tools for school management: A survey of secondary school managers' perceptions. Journal of the Social Sciences, 48(3), $2559-2572$.

Unodiaku, S. S. (2013). Influence of sex and ability level on students' Mathematics readiness in Enugu State. Journal of Education and Practice, 4(14), 73-78. http://eprints.gouni.edu.ng/173/1/6800-8910-1-PB.pdf

USA FACTS (2020). 4.4 million households with children don't have consistent access to computers for online learning during the pandemic. https://usafacts.org/articles/internet-access-students-at-home/

Yang, S., Hsu, W., \& Chen, H. (2016). Age and gender's interactive effects on learning satisfaction among senior university students. Educational Gerontology, 42(12), 835-844. https://doi.org/10.1080/03601277.2016.1231514 